$\xi=\mathrm{r}$

\title{
Problem educate psychological development of children in Iranian cinema
}

\author{
Behzad Asadi $^{1}$ *, Mojtaba Cheraghsahar ${ }^{2}$, Ehsan Karamuzravari ${ }^{3}$ \\ ${ }^{1}$ MA, dramatic literature, University of Bushehr, Iran . Civil Engineer, University of Damavand, Iran \\ ${ }^{2}$ MA, dramatic literature, University of Bushehr, Iran \\ ${ }^{3}$ MA, Dramatic litterateur. soore Institute. Iran \\ *Corresponding author E-mail: behzad_asadi64@yahoo.com
}

\begin{abstract}
Cinema as an important tool of socialization in the modern world, with representation of the pattern of social life such as theatrical performances, and the reproduction of these norms constitutes de facto role in public life today is responsible. Cinema for children as well as educational facilities for proper display the behavior and character of an area suitable for children provides studies. In this research, the video review after the revolution Iranian cinema to an audience of children's mental development problems in education.
\end{abstract}

Keywords: Children; Psychological Development; The Movie; Iranian Cinema.

\section{Introduction}

\subsection{The impact of movies on children}

Film as one of the most important mass media in the daily lives of individuals, businesses and social structure of human life, how to communicate in-group and out-group and even ideas for how to live with each person. So that one could claim that ideas, thoughts, beliefs, attitudes and a general trend, the philosophy of life with the film are formed, changed, modified or destroyed .... For example, a couple's separation, seeing a movie where one of the parties over and sacrifice continuation of the marriage, or display the consequences of divorce, re-bonded and nothing but the effect of amazing movies on not people.

With a little attention to the daily lives of individuals, can be the role of film in taste and growing public opinion realized and that of the way ideas and tastes of New persons were formed, and even in the conduct of their Appears. Is that more and more artists and film-makers in the task of reconstruction will be realized or fall Nations.

At this point we're trying to escape the current scourge of our society. The flagship cultural invasion is nothing but a satellite and movies that through the waves, thoughts and desires of other communities in the West with the injection.

\subsection{The overall impact movies}

The content of the videos could be the viewer in a state like artificial sleep. So that if the events shown in the film occur in a real environment, milder reactions draw, or perhaps not with such reactions. Of course, this is not the same effect on all people.Specifications spectators when watching movies on the one hand, and the technical aspects of the film are double agents who need to justify and influence the audience in mind. However, films have the greatest impact on children and young people have little knowledge.
Videos enhanced effect even in children's games. The destructive effect of the film is as much a study in France showed a child or teenager who goes to the cinema more than once a week is in need of psychiatric care. Because the impact of destructive films made in the country (as smuggling and illegal import of Iran, or through satellite transmission, termite-like and by parents unaware of the homes we come) that is stimulated by intense emotion, create chaos, disorder is caused by emotions far more than its educational role.

The impact of TV on children as it is for children, the film is nothing but the truth. In other words, the child is given to films of imagination. In his view, what he sees is a part of real life. Especially when the content of a stretch films for children and is charming.Such as defense or martial arts movies full of action for the boys! Thus, along with the actors to be happy, be sad, anxious and distraught at the events remains

In short, the children in your mind and sometimes in practice, the movie plays.

\subsection{Annie imitation}

Sometimes the effect of videos of the imitation Annie goes and long life-changing and making his character initiates or changes, because the wishes and feelings of the films to be screened. According to the study, the effect of children eight to eleven years is very intense. Dell's film closes, actively participate in the adventures of the sequence of events with their creative minds estimates and film heroes, especially his favorite characters - matched up. In this age of the child heroes of the film are the most powerful. Children of the evil and the good script or does not know what he wants to inspire in his mind. The only real movie adventures thinks and does not know what he sees nothing but the truth. What is important is what is happening and people: This is what the actor does and what the reaction of events dealing with the symptoms. 
Began to enter the world of adolescence, something that is of primary importance in people's properties. culture society. It is extreme in your worship lead actors.

\subsection{Basic risk}

Pornographic movies fundamental risks for the individual and for society to follow. The destructive impact of films that are smuggled and illegally entering the country, to dare without measure. Most of these movies contain themes are immoral and deviant scenes a lot of them to be exhibited. These films not only for children but also for young people is very harmful and dangerous.

Poisoning the minds of the younger generation and the future of every society, as the loss of personal and national identity of the country. See inappropriate videos, but the learning outcomes acts and the depletion of the country's culture and civilization in the minds of young people and not the future. Young Teen learns to lie, aggression, and his instincts to satisfy any kind of act.

Sexual from birth for decentralized child there and gradually changes shape and is certain if the natural and human dignity emerge and evolve, ultimately sacred institution called family foundation; but if error way to travel, not only brings life to decline, but the society to self-abandonment and moral chaos leads. Interestingly, scholars and thinkers of Western societies, the situation is critical.

\section{Concepts and theoretical foundations}

\subsection{Table of psychosocial development - social}

Human growth over the course of childhood is not finished, but a continuous process from birth to adulthood and old age range. Physical changes throughout life happens and attitudes, and behavior affects cognitive processes. They are the kinds of issues that people have to cope with different life in different periods. Erik Erikson, a psychoanalyst, a system Hshtmrhlhay to describe the growth of life offered, and the psycho - social (psychosocial stages) called, because he believes that spiritual growth depends on social relations in particular, who at different times during the establish their lives. In each of these stages, people with special social problems or crises faced. Stages of psychosocial development - Erikson's stages of psychosocial development table Social shown. (Ravadrad, A. 2001)

\section{Findings}

Birthday children's films in the "modern Iranian cinema." In 1363 with the construction of puppet films in mice directed by Marzieh Boroumand, Mohammad Ali Talebi as the first official children's films to the children of the gift and the story of the new structure of fantasy and creativity and innovation to the attention of the vast majority of children were new direction for children's theater and cinema was a Sharif theater where the child was.

This process could go either way until Kambozia ray film Gulnar for children Iran brought, Gulnar that as a turning point in children's films in Iran is due to the creativity of countless beam as well as the musical and fantasy characterization of his principle that all credible for children were able to achieve impressive sales and bring many children into the hall theaters in the country.

Ferial Behzad this year with two films valley Moth and tassels to welcome the children came, M. dignity Patal and Aspirations small for children interested in imagining and wishes did not achieve much they had brought in so the shortly many good filmmakers in Iranian cinema films produced for children's films. Abolhassan Davoudi, M. artist, Ismail BARARI, Bijan colorless and Masoud Rassam, including filmmakers, celebrities who make films like Thief dolls, magical journey, the city in the hands of children, Ali and the Giant Forest, sappy and Mangool, cats singing school old Men, Mary and the oil film like this with all good children faced and videos desirable in the genre were children's, children's films to flourish and has the desired effect of your labor in the feedback behavior of children and enthusiastically welcomed to watch the videos were viewed.( Bashiriyeh, H.2001).

Another important points that in most movies so childish in Iranian Cinema seen is that most filmmakers, their films for adult audiences made only by means of one or two children in the film or focus put it in the film try to film as a film for children to suck your contacts have the same makes no trust in this type of film, the film's not just the name of the child and to fully adult, the movie children's film that only a few children have attended, the film is a film for children to help children's growth and development , As well as vice versa, this is another way to be seen and it is in films for children should be content to adults is also included, as children often with adults (parents, coaches, etc.) to watch movies on the go these films have adult will also be pleased to have your children to watch movies in the theater, take this important feature in the cinema blockbusters of children in Iran as seen for example in two films Gulnar and red hatand cousin (two blockbuster movies of children in Iran) this feature is objectified. (Kochi Moradi, SH.2002).

Finally, in films for children should be a world of mobility, light, color, imagination, joy, etc. People and videos away from any big if given the capacity for children's intellectual construct, video production and special programs childish with views of specialization and by people competent to be made that unfortunately developers children on TV or those involved in children's films are completely unprofessional and without the benefit of child psychology, to film and various programs are this caused everyone to sort out their heart-stricken children experiencing a crisis in their strange!.(Rahmati, Mohseni Tabrizi .2003).

\section{Conclusion}

the role of children in the production of the film, the two characters was briefly: illegitimate children and missing children, and usually to play these roles as well, especially from the forties to mid-fifties began more than two or three children considered Nmyshd.v only fit the face Zah there is no news business and is one of the films about children, the King of hearts sample presence of children in a role Melo drama.

Cinema before the revolution. Ever since the major markets of films for children in the hands of foreign companies and Iranian films for children did not exist. (Screenshot below) in mice if the Institute for the Intellectual Development of Children and Young Adults with the aim of making films for children since 1384 his artistic career starts this primary production is so limited release were that allows audiences child deprived of them had been and Chorus (Abbas Kiarostami) Salkh product either because they are in the category of films about children and because of limited release so your audience will not be widely welcomed, and in 1364 a work of cinematic productions for children Nmyshvd.bh seen in terms of mortality Dam main reason for this gap, changing political conditions, the beginning of the war and social issues, the border is that while the emergence of new filmmakers in cinema, but due to the changed conditions and replacement pressing issues, instead, the issue of children's films so ignored in the early years of the Islamic revolution, but two iconic movies, no other feature film about the child also does not cause even terms in recent years has been repeated again. Since the beginning of President Mohammad Khatami in 1367 so far (mid-1379), series production of films for children are limited to film one was not one that tries to appeal to the core audience his own children, and in front of the number of films about for example, the Kvdkan.bhHamad Raza video artist who steals her dolls of the most popular children's films in the history of Iranian cinema in 1377 and 1387. The Wrong Man Mummy 3 makes both adult audience. (Sadr, HR $.2002)$. 
Lack of support centers, children's cinema production of the most important children's films. From 1354 until now, the main center of cultural activities, art and theater for children, Center for Intellectual Development of Its focus because of employment in various fields, according to the film section less. Besides the center, the Ministry of Education also modest activities in the field of film and television has done, but this limited production to meet the massive audience of children and adolescents are not even festival growth (which is a continuation of International Children's Festival andteens before the revolution) or does a movie theater (cinema Palestine) to the festival for products cinematic Ministry of education has virtually stagnated was because we see at the cinema Palestinian films for children and adolescents in taken no other than the two produced the rest of those involved in film production, films for children avoided in most cases if a producer to make a film about children, he (according to past experience) mostly due to attract foreign audiences and sell it in Market An international community.(Nayebi, H. and H. Abdollahyan .2002).

\section{References}

[1] ARavadrad, A. (2001) "film, two women and a red sociological analysis", Tehran: Farabi, Volume 9, No. 4

[2] Sadr, HR (2002) an introduction to the history of Iranian cinema, Tehran: Reed Publishing.

[3] Kochi Moradi, SH (2001) "firm boundary image of women in Iranian cinema," al-Farabi, Volume 11, No. 2 and 3.

[4] Bashiriyeh, H. (2001) theories of culture in the twentieth century, Tehran: Institute Snoopy future.

[5] Rahmati, Mohammad Mehdi Alireza Mohseni Tabrizi (2003), "Siri on the concepts and theories of violence, aggression and aggression in order to build and deliver a causal model describe violence in sport", a Social Science Faculty of Social Sciences, Tehran University, No. 19.

[6] Nayebi, H. and H. Abdollahyan (2002), "explain the social stratification", a Social Science Faculty of Social Sciences, Tehran University, New Era, No. 20. 